\title{
Temperature-Dependent Raman Spectroscopic Study of the Double Molybdate $\mathrm{KBi}\left(\mathrm{MoO}_{4}\right)_{2}$
}

\author{
Min Wang ${ }^{1}$, Changhao Wang ${ }^{2}$, Jian Wang ${ }^{1}$, Liming Lu ${ }^{3}$, Xiaoye Gong ${ }^{1}$, Xiaohui Tang ${ }^{1}$, \\ Fu Zhang ${ }^{1}$ and Jinglin You ${ }^{1, *(D)}$ \\ 1 State Key Laboratory of Advanced Special Steel, School of Materials Science and Engineering, Shanghai \\ University, Shanghai 200444, China; wang_min@shu.edu.cn (M.W.); wang_jian@shu.edu.cn (J.W.); \\ crusenicd@shu.edu.cn (X.G.); xhtang_gray@shu.edu.cn (X.T.); zhangfu@shu.edu.cn (F.Z.) \\ 2 Key Laboratory of Infrared Imaging Materials and Detectors, Shanghai Institute of Technical Physics, \\ Chinese Academy of Sciences, Shanghai 200083, China; ch14820189@shu.edu.cn \\ 3 CSIRO Mineral Resources, Technology Court, Pullenvale, QLD 4069, Australia; Liming.Lu@csiro.au \\ * Correspondence: jlyou@staff.shu.edu.cn
}

Received: 29 October 2020; Accepted: 25 November 2020; Published: 30 November 2020

\begin{abstract}
In situ high-temperature Raman spectra of polycrystalline $\mathrm{KBi}\left(\mathrm{MoO}_{4}\right)_{2}$ were recorded from room temperature to $1073 \mathrm{~K}$. Thermal stability of the monoclinic $\mathrm{KBi}\left(\mathrm{MoO}_{4}\right)_{2}$ was examined by temperature-dependent XRD. The monoclinic phase transformed into the scheelite tetragonal structure at $833 \mathrm{~K}$, and then to the monoclinic phase at $773 \mathrm{~K}$. Quantum chemistry ab initio calculation was performed to simulate the Raman spectra of the structure of $\left.\mathrm{KBi}_{(\mathrm{MoO}}\right)_{2}$ high-temperature melt. The experimental Raman band at $1023 \mathrm{~K}$ was deconvoluted into seven Gaussian peaks, and the calculated results were in good agreement with the experimental data. Therefore, the vibrational modes of Raman peaks of molten $\mathrm{KBi}\left(\mathrm{MoO}_{4}\right)_{2}$ were assigned. It was confirmed that the isolated structure of $\left[\mathrm{Bi}\left(\mathrm{MoO}_{4}\right)_{2}\right]^{-}$ monomer, consisting of $\mathrm{Mo}^{6+}$ centers and $\mathrm{Bi}^{3+}$ sub-centers connected by edge-sharing, mainly exists in the melt of $\mathrm{KBi}\left(\mathrm{MoO}_{4}\right)_{2}$.
\end{abstract}

Keywords: high-temperature Raman spectroscopy; quantum chemistry ab initio calculation; structure of melt

\section{Introduction}

Double molybdates have attracted extensive interest due to their potential applications in various fields of science and technology [1]. Compounds with the general formula $\mathrm{ARE}\left(\mathrm{MO}_{4}\right)_{2}(\mathrm{~A}=\mathrm{Li}, \mathrm{Na}$, $\mathrm{K}, \mathrm{RE}=$ rare earth or $\mathrm{Bi}$, and $\mathrm{M}=\mathrm{W}$ or $\mathrm{Mo}$ ) have wide application as hosts for lasers, fluorescence, and scintillating materials [2-5], due to their excellent chemical durability in air atmosphere, high rare earth ion admittance, large absorption, and emission cross-sections of rare earth ions in their lattice [6-17]. Double molybdates of monovalent and trivalent cations have the following three characteristics reported by Isupov [18]: (i) there are many combinations of monovalent $(\mathrm{Li}, \mathrm{Na}, \mathrm{K}, \mathrm{Rb}, \mathrm{Cs}, \mathrm{Tl}, \mathrm{Ag}$ ) and trivalent (Al, Sc, Fe, Ga, Y, In, La-Lu, Bi) elements in compounds, (ii) the number of crystal types of these compounds is large, and (iii) there are numerous reconstructive phase transitions which differ from the displacement transitions. Regarding the discovery, synthesis, and physicochemical examination of double molybdates with all possible compositions and different cation valences, relevant research began intensively decades ago and has been continuously developing with undiminished interest [19-23].

Much attention has been paid to the rare earth doped bismuth molybdates and tungstates. In particular, double potassium bismuth molybdate $\mathrm{KBi}\left(\mathrm{MoO}_{4}\right)_{2}$ are generally used as promising hosts for a variety of luminescent $\mathrm{RE}^{3+}$ ions, such as the doped $\mathrm{Cr}^{3+}: \mathrm{KCr}_{\mathbf{x}} \mathrm{Bi}_{1-\mathrm{x}}\left(\mathrm{MoO}_{4}\right)_{2}$ system [24-26]. It was reported that the $\mathrm{KBi}\left(\mathrm{MoO}_{4}\right)_{2}$ ceramic showed a distorted scheelite structure and a very low sintering 
temperature around $903 \mathrm{~K}$ [27]. Infrared and Raman spectroscopy were used by Hanuza et al. [28] to obtain the distribution of vibrational levels, the symmetry, and assignment to the respective normal modes of $\mathrm{KBi}\left(\mathrm{MoO}_{4}\right)_{2}$ crystal. The transformation of $\alpha-\mathrm{KBi}\left(\mathrm{MoO}_{4}\right)_{2}$ into the disordered $\mathrm{CaWO}_{4}$ structure took place continuously and was accompanied by a very weak endothermic effect [29]. High-temperature melt is the mother liquor of crystal growth; however, the structure of double molybdate melt still remains unknown.

This study attempts to derive the structure information of the melt of $\mathrm{KBi}\left(\mathrm{MoO}_{4}\right)_{2}$ from high-temperature Raman spectroscopy, mainly including the structural units in atomic scale and the existing form of multi-molecular clusters structure. In the present paper, we report the temperature-dependent Raman spectroscopy studies of polycrystalline $\mathrm{KBi}\left(\mathrm{MoO}_{4}\right)_{2}$ from room temperature to $1073 \mathrm{~K}$ in order to obtain information on the structural changes that occur in this material. High-temperature X-ray diffraction (XRD) was also carried out to characterize the thermal stability of the room temperature phase. Quantum chemistry ab initio calculation was carried out to explore the structure of $\mathrm{KBi}\left(\mathrm{MoO}_{4}\right)_{2}$ in the molten state.

\section{Materials and Methods}

The starting materials of $\mathrm{K}_{2} \mathrm{CO}_{3}, \mathrm{Bi}_{2} \mathrm{O}_{3}$, and $\mathrm{MoO}_{3}$ (analytically pure from Sinopharm Chemical Reagent Co., Ltd., Shanghai, China) were used in the experiment without any purification or treatment. The synthesis of $\mathrm{KBi}\left(\mathrm{MoO}_{4}\right)_{2}$ compound was achieved via the melting method, in which the stoichiometric ratio of the original reagents was mixed, uniformly ground, and then heated in a platinum crucible. The temperature control settings are shown in Table 1.

Table 1. The temperature control settings used for the synthesis of $\mathrm{KBi}\left(\mathrm{MoO}_{4}\right)_{2}$ crystal.

\begin{tabular}{ccc}
\hline Temperature Point/K & Holding Time/min & Heating or Cooling Rate/K' $\mathbf{m i n}^{\mathbf{- 1}}$ \\
\hline 298 & - & 4.92 \\
\hline 593 & 60 & \\
723 & 30 & 1.14 \\
823 & 30 & \\
923 & 60 & \\
1023 & 60 & \\
1073 & 60 & The melt cooled down slowly (0.25 K/min) to $473 \mathrm{~K}$, \\
473 & - & and then cooled in the furnace to room temperature. \\
\hline
\end{tabular}

The phase identification was performed using a D8 Advance diffractometer (Bruker AXS, Karlsruhe, Germany) with $\mathrm{Cu} \mathrm{K} \alpha$ radiation in the Bragg-Brentano geometry mode. Temperature-dependent XRD data were collected from room temperature (RT) up to $933 \mathrm{~K}$ under air atmosphere in the $2 \theta$ range of $5-70^{\circ}$ with a step size of $0.016^{\circ}$ and an acquisition time of $0.5 \mathrm{~s} / \mathrm{step}$. The powder sample was placed in a platinum-lined corundum sample holder and then heated in a high-temperature chamber (HTK 1200N, Anton Paar, Austria). The collected diffraction data were analyzed using the JADE 6.0 software with the JCPDS-ICDD Powder Diffraction File database.

In situ high-temperature Raman spectra of $\mathrm{KBi}\left(\mathrm{MoO}_{4}\right)_{2}$ crystal were recorded with a laser confocal Raman spectrometer (LabRAM HR800, Horiba Jobin Y'von, France), which was equipped with an intensity charge coupled device (ICCD) detector for signal enhancement at high temperature. The microscopic heating furnace (Linkam, TS1500, Tadworth, UK) was used to achieve the heating and cooling (the rate controlled at $5 \mathrm{~K} / \mathrm{min}$ ) of the sample in the temperature range from RT to $1073 \mathrm{~K}$ with a precision of $\pm 1 \mathrm{~K}$. Each Raman spectrum was collected after keeping the sample for $10 \mathrm{~min}$ at the given temperature, which was helpful for elimination of the hysteresis of structural changes induced by temperature. The $532 \mathrm{~nm}$ line of a Q-switch pulsed SHG-Nd:YAG laser (Coherent, Santa Clara, CA, USA) was used as an excitation source. In this study, the slits were set for a resolution of about $1 \mathrm{~cm}^{-1}$. 
In order to explore the melt structure of $\mathrm{KBi}\left(\mathrm{MoO}_{4}\right)_{2}$, a series of typical structural units and their multi-molecular clusters structure were designed. $\mathrm{Ab}$ initio calculation, a powerful quantum chemistry program for studying finite scale systems [30,31], was performed to study the short-range ordered clusters structure and their properties dependent on this scale of order. The geometry configuration of the designed structural models in the melt of $\mathrm{KBi}\left(\mathrm{MoO}_{4}\right)_{2}$ was first optimized before simulating their vibrational Raman spectra using the Gaussian 09 software package. A pseudopotential basis set of LanL2DZ [32,33] and the method of Restricted Hartree-Fock (RHF) [34] were adopted. The single point energy of the cluster structure models with the singlet spin was selected to obtain the ground state.

\section{Results and Discussion}

\subsection{Temperature-Dependent XRD Spectra}

At room temperature and in atmospheric pressure, the crystallization of $\mathrm{KBi}\left(\mathrm{MoO}_{4}\right)_{2}$ is monoclinic belonging to the space group $P 2_{1} / c\left(C_{2 h}{ }^{5}\right)$, with twelve molecules in the unit cell. It is isostructural with $\alpha-\mathrm{KSm}\left(\mathrm{MoO}_{4}\right)_{2}$ for which $a=16.69, b=23.85, c=5.30$, and $\beta=91.3^{\circ}$ [28,35]. Some studies have indicated that at temperatures close to the melting or decomposition point, most double molybdates show the tetragonal scheelite structure with a centrosymmetric space group (SG) $I 4_{1} / a$ (No. 88) [17]. The structure of $\mathrm{KBi}\left(\mathrm{MoO}_{4}\right)_{2}$ is reported to be similar to the distorted scheelite-type $\left(\mathrm{CaWO}_{4}\right)$ structure [36].

High-temperature XRD of the $\mathrm{KBi}\left(\mathrm{MoO}_{4}\right)_{2}$ was performed in order to examine the thermal stability of the monoclinic phase, as is shown in Figure 1. Upon heating, nearly all the diffraction peaks shifted to lower Bragg angles. The XRD pattern changed significantly from $783 \mathrm{~K}$ to $833 \mathrm{~K}$, especially the disappearance of the peaks in the $2 \theta$ range of $27.2-27.5^{\circ}, 32-34^{\circ}, 44-48^{\circ}$, and $54-57^{\circ}$, and the new appearance of the peaks at $27.3^{\circ}, 32.8^{\circ}$, and $44.5^{\circ}$, which is recognized as the characteristics of the scheelite tetragonal structure. In the low Bragg angle range $\left(<25^{\circ}\right)$, the diffraction peaks disappeared completely at $833 \mathrm{~K}$. That is, as the temperature increased, the split peaks that represent the monoclinic symmetry gradually merged into one, and the ratio of the peak intensities changed with the transformation into a tetragonal structure. The splitting gradually disappeared toward $833 \mathrm{~K}$, and the structure became fully tetragonal with the $I 4_{1} / a$ space group. The order-disorder transformation of $\mathrm{Bi}^{3+}$ and $\mathrm{K}^{+}$cations gradually occurred in the crystal structure. Some earlier studies indicated that the low-temperature monoclinic phase of $\mathrm{KBi}\left(\mathrm{MoO}_{4}\right)_{2}$ continuously transforms to the high-temperature disordered tetragonal scheelite structure in the temperature range $\Delta \mathrm{T} \geq 150 \mathrm{~K}$ and is completed at $933 \mathrm{~K}$, accompanied by a very weak endothermic effect $[29,37]$. The observed diffraction change from monoclinic to tetragonal is consistent with those reported data. After the temperature decreased to $773 \mathrm{~K}$, a diffraction pattern of monoclinic appeared, but there was still a certain difference from the diffraction spectrum of $783 \mathrm{~K}$. This is probably because the phase structure could not be completely restored due to the faster cooling rate $(10 \mathrm{~K} / \mathrm{min})$. Therefore, it can be inferred that the phase transition from monoclinic to tetragonal may be reversible at about $773 \mathrm{~K}$ when the cooling rate is slow enough. After cooling down to room temperature, the diffraction pattern showed monoclinic reflections. However, the positions of the diffraction peaks after cooling to room temperature had a shift, the intensities of the peaks were lower, and the half-widths of the peaks became larger than those at room temperature before heating. This demonstrates that the monoclinic structure was reobtained, but not completely. 


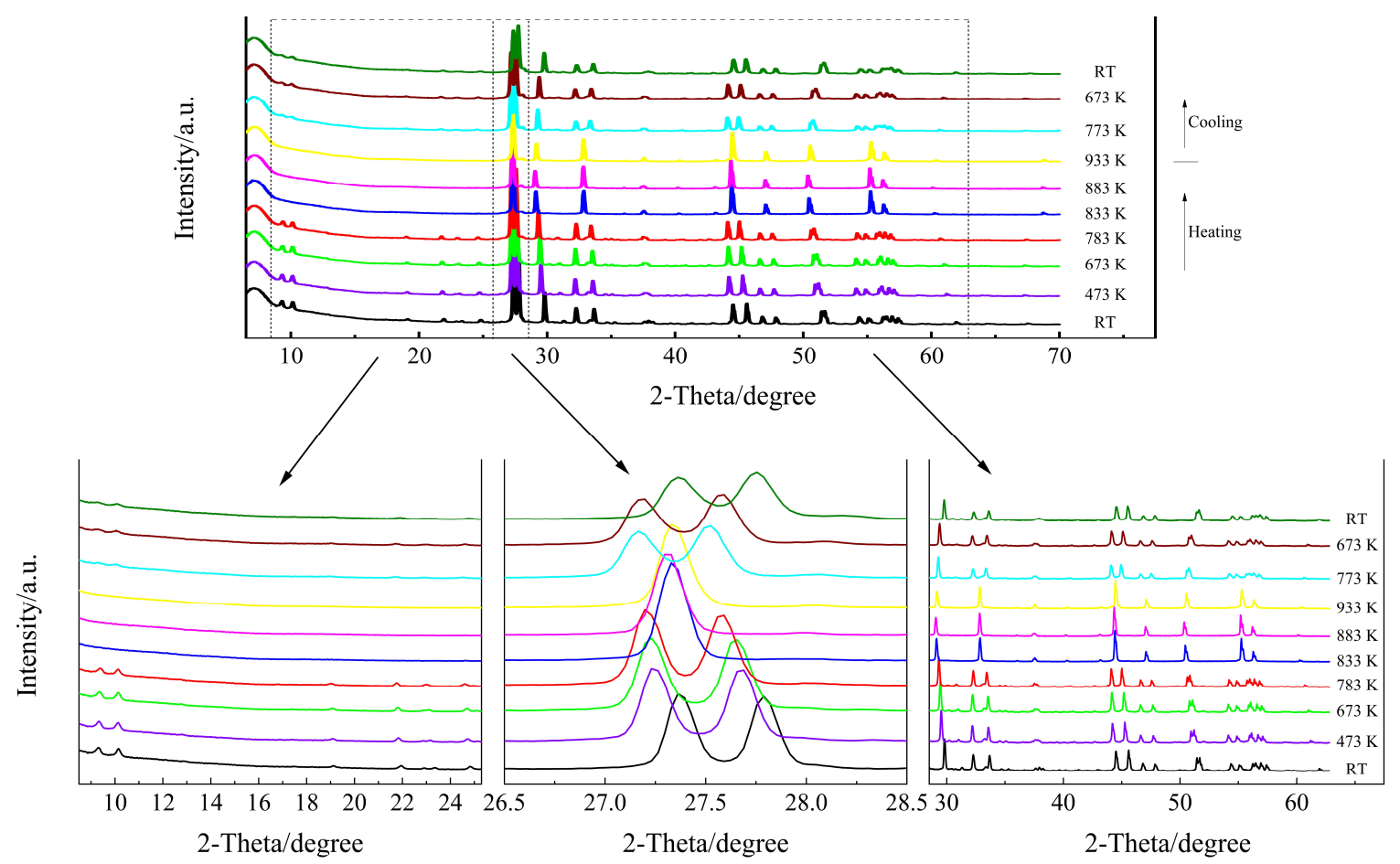

Figure 1. High-temperature XRD patterns of $\mathrm{KBi}\left(\mathrm{MoO}_{4}\right)_{2}$, where RT stands for room temperature.

\subsection{Temperature-Dependent Raman Spectra}

For the monoclinic $\mathrm{KBi}\left(\mathrm{MoO}_{4}\right)_{2}$, according to the factor group analysis (FGA), the 432 vibrational modes were predicted: $\Gamma=108 A_{g}+108 B_{g}+108 A_{u}+108 B_{u}$ where $A_{u}+2 B_{u}$ are acoustic modes. There are 429 optical zonecenter modes, 216 of which are Raman-active only and 213 of which are IR-active only. It is reported that the predicted vibrational modes were distributed among $54 A_{g}+54 B_{g}+54 A_{u}+54 B_{u}$ internal modes, $18 A_{g}+18 B_{g}+18 A_{u}+18 B_{u}$ librational modes, and $36 A_{g}+36 B_{g}+35 A_{u}+34 B_{u}$ translational modes [28]. According to selection rules, only $A_{g}$ and $B_{g}$ are Raman-active.

Raman spectra of $\mathrm{KBi}\left(\mathrm{MoO}_{4}\right)_{2}$ crystal at room temperature are present in Figure 2. It is obvious that the number of vibrational modes observed is much smaller than that predicted for the $\mathrm{KBi}\left(\mathrm{MoO}_{4}\right)_{2}$, which is caused by the polycrystalline samples in the measurement. When it comes to solid-state Raman band distribution, a more appropriate distinction is made between internal and external lattice vibration modes. The most intense lines at 952 and $866 \mathrm{~cm}^{-1}$ are attributed to the symmetric and asymmetric stretching vibrations of $\mathrm{MoO}_{4}$, respectively. The Raman band in the middle frequency region of $580-750 \mathrm{~cm}^{-1}$ is characteristic of the vibrations of double $\mathrm{MoO}_{2} \mathrm{Mo}$ and single bridge MoOMo, which formed due to the intermolecular interactions that exist in the unit cell. The assignment of the major Raman vibrational modes of monoclinic $\mathrm{KBi}\left(\mathrm{MoO}_{4}\right)_{2}$ is displayed in Table 2.

In situ high-temperature Raman spectra of $\mathrm{KBi}\left(\mathrm{MoO}_{4}\right)_{2}$ from room temperature to $1023 \mathrm{~K}$ in the wavenumber range of $200-1200 \mathrm{~cm}^{-1}$ are shown in Figure 2a. As the temperature increased from room temperature to $923 \mathrm{~K}$, the overall line shapes of the Raman spectra had no obvious change, whereas the full width at half maximum (FWHM) of nearly all the Raman peaks increased and their intensities decreased, which is shown more clearly in Figure $3 \mathrm{~b}$. With temperature increasing from RT to $773 \mathrm{~K}$, the adjacent weak and shoulder Raman peaks merged with the major one. It can be seen from Figure 3a that the modes located at 347, 373, 404, 704, 823, 866, 933, and $952 \mathrm{~cm}^{-1}$ exhibited a decrease in wavenumber, whereas the modes of 294,593 , and $739 \mathrm{~cm}^{-1}$ showed a linear increase with increasing temperature. The structure gradually relaxed with broadening distribution of atomic bond distances and bond angles due to thermal expansion and thermal disorder. With a further temperature increase to $923 \mathrm{~K}$, the vibrational modes of $342,401,822$, and $930 \mathrm{~cm}^{-1}$ (monoclinic phase at $773 \mathrm{~K}$ ) disappeared, while the modes of $298,319,700$, and $751 \mathrm{~cm}^{-1}$ increased obviously in wavenumber. 
The Raman response was still very well-defined at $923 \mathrm{~K}$, but it was suddenly strongly diffused at $1023 \mathrm{~K}$. At first sight, such spectral evolution should be related to structural phase transitions. Combined with the high-temperature XRD results, it can be determined that at $833 \mathrm{~K}$ the monoclinic phase of $\mathrm{KBi}\left(\mathrm{MoO}_{4}\right)_{2}$ to the tetragonal transformation occurred. A similar pseudo-tetragonal lattice distortion appearing in $\mathrm{KBi}\left(\mathrm{MoO}_{4}\right)_{2}$, which was attributed to the ordering of the $\mathrm{K}^{+}$and $\mathrm{Bi}^{3+}$ ions [37], may explain the slow and continuous change of Raman spectra before this transition. Figure $2 b$ demonstrates the deconvolution of Raman spectra corresponding to the experimental temperatures by Gaussian and Lorentz function for the molten spectrum and the other spectra, respectively. The spectrum of the $\mathrm{KBi}\left(\mathrm{MoO}_{4}\right)_{2}$ melt was deconvoluted into seven Gaussian Raman peaks at $1023 \mathrm{~K}$. The dramatic changes in the Raman spectra from $923 \mathrm{~K}$ to $1023 \mathrm{~K}$ were due to the solid-liquid phase transformation, and the tetragonal crystal structure was destroyed and in a completely molten state.
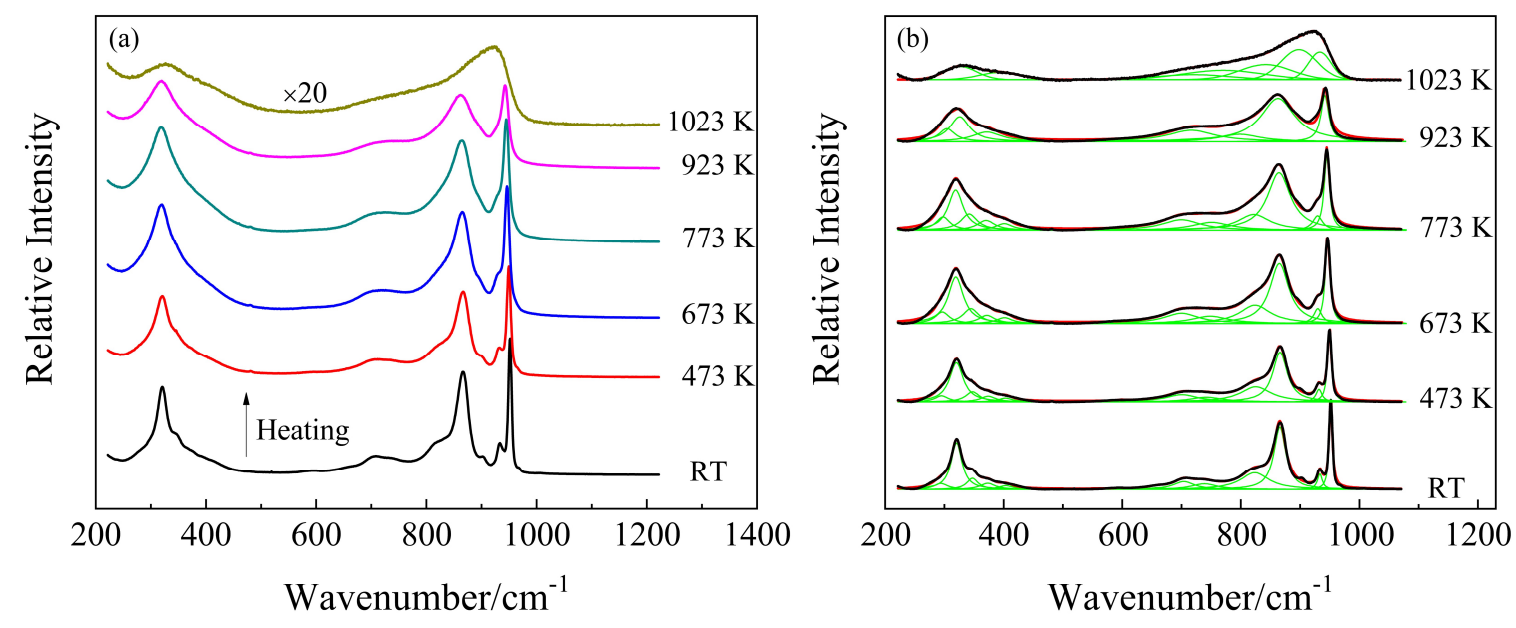

Figure 2. (a) Temperature-dependent Raman spectra of polycrystalline $\mathrm{KBi}\left(\mathrm{MoO}_{4}\right)_{2}$ from room temperature to $1023 \mathrm{~K}$; (b) deconvolution of Raman spectra by Gaussian (1023 K) and Lorentz (from RT to $923 \mathrm{~K}$ ) function as a function of temperature.

Table 2. The assignment of major vibrational modes of crystalline $\mathrm{KBi}\left(\mathrm{MoO}_{4}\right)_{2}$.

\begin{tabular}{|c|c|c|}
\hline \multicolumn{2}{|c|}{ Wavenumber/cm ${ }^{-1}$} & \multirow{2}{*}{ Type of Vibration } \\
\hline$v_{\text {exp. }}$ & $v_{\text {ref. }}[23]$ & \\
\hline 952 & 948 & \multirow{3}{*}{ symmetric stretching vibrations of $\mathrm{MoO}_{4}$} \\
\hline 933 & 929 & \\
\hline 902 & 898 & \\
\hline 866 & 863 & \multirow{6}{*}{$\begin{array}{l}\text { asymmetric stretching vibrations of } \mathrm{MoO}_{4} \text { with } \\
\text { stretching vibrations of } \mathrm{Mo}_{2} \mathrm{O}_{8} \text { bridge }\end{array}$} \\
\hline 823 & 815,830 & \\
\hline 739 & 736 & \\
\hline 704 & 704 & \\
\hline 658 & - & \\
\hline 593 & 580 & \\
\hline 404 & - & \multirow{3}{*}{ asymmetric bending vibrations of $\mathrm{MoO}_{4}$} \\
\hline 373 & 376,365 & \\
\hline 347 & 343 & \\
\hline 320 & 320 & \multirow{2}{*}{ symmetric bending vibrations of $\mathrm{MoO}_{4}$} \\
\hline 294 & 282 & \\
\hline
\end{tabular}



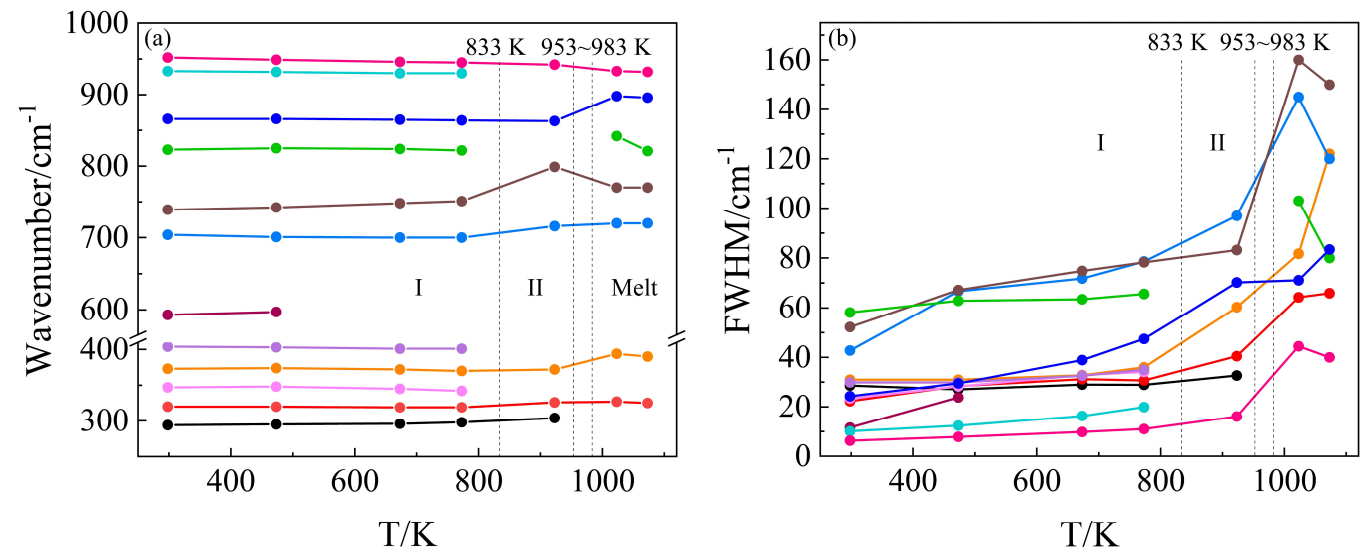

Figure 3. (a) Wavenumber versus temperature and (b) full width at half maximum (FWHM) versus temperature plot for the major stretching and bending vibrational modes of $\mathrm{KBi}\left(\mathrm{MoO}_{4}\right)_{2}$. The vertical dashed lines indicate the reported temperature [27,37] at which the phase transition (phase I: monoclinic, phase II: tetragonal, and the melting point of 953-983 K) takes place.

\subsection{Structure of Molten $\left.\mathrm{KBi}_{(\mathrm{MoO}}\right)_{2}$}

The Raman spectrum of the molten $\mathrm{KBi}\left(\mathrm{MoO}_{4}\right)_{2}$ at $1023 \mathrm{~K}$ is shown in Figure 4 . The whole envelope was deconvoluted by Gaussian function after subtracting the baseline of the spectrum. The anion motifs of isolated $\left[\mathrm{MoO}_{4}\right]^{2-}$ tetrahedra have been reported to exist in the melt of alkali metal monomolybdates [38,39]. $\mathrm{KBi}\left(\mathrm{MoO}_{4}\right)_{2}$ has the same chemical ratio as $\mathrm{K}_{2} \mathrm{MoO}_{4}$; however, their band shapes and positions are quite different. This indicates that the melt structure of $\mathrm{KBi}\left(\mathrm{MoO}_{4}\right)_{2}$ cannot be the simple monomer of $\left[\mathrm{MoO}_{4}\right]^{2-}$. Nevertheless, on the basis of the distribution of different structural units previously studied [40], the six coordinated $\left[\mathrm{MoO}_{6}\right]^{6-}$ cannot be the primary structure in the melt of $\mathrm{KBi}\left(\mathrm{MoO}_{4}\right)_{2}$. From the positions of the deconvoluted Raman peaks, the four coordinated tetrahedral $\left[\mathrm{MoO}_{4}\right]^{2-}$ can be confirmed to be present in the melt.

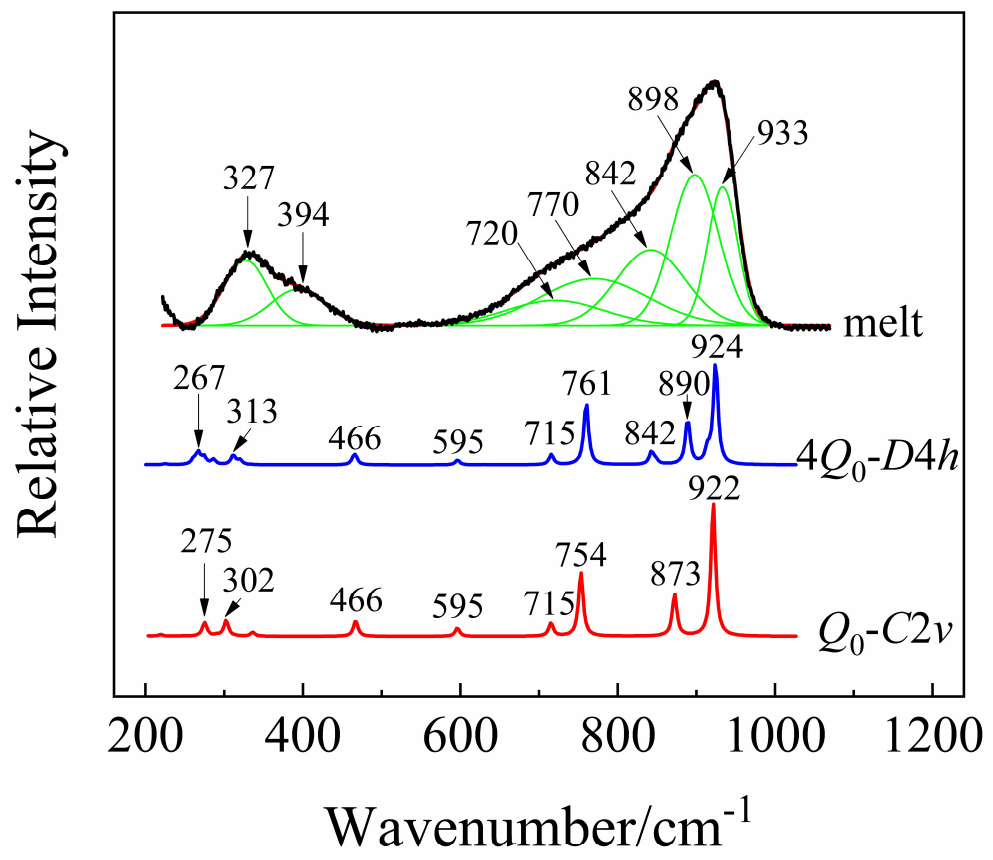

Figure 4. The deconvolution of Raman spectrum for the melt of $\mathrm{KBi}\left(\mathrm{MoO}_{4}\right)_{2}$ at $1023 \mathrm{~K}$ by Gaussian function, and the calculated Raman spectra by quantum chemistry ab initio calculation, where $Q_{0}$ and $4 Q_{0}$ represent the structural unit and the corresponding multi-molecular clusters structure containing four structural units. 
In order to further examine the structural unit and its multi-molecular clusters structure in the melt of $\mathrm{KBi}\left(\mathrm{MoO}_{4}\right)_{2}$, quantum chemistry ab initio calculation was performed for the optimization and simulation of the vibrational properties of the designed structure. Considering the large electronegativity of the heavier $\mathrm{Bi}$ atom, the $\left[\mathrm{MoO}_{4}\right]^{2-}$ group is more likely to be coordinated to $\mathrm{Bi}^{3+}$ than $\mathrm{K}^{+}$. Therefore, a model of "double-center" structure with $\mathrm{K}^{+}$acting as the charge compensation was proposed and illustrated in Figure 5a. Due to the strong attraction of Bi to electrons, it will compete for the non-bridging oxygens around Mo atoms, thereby increasing the number of bridging oxygens in the system. Note that $\mathrm{Bi}$ is a sub-center, while $\mathrm{Mo}$ is still the center of the entire structural system. The oxygen atoms coordinated to $\mathrm{Bi}$ are also shared by the $\left[\mathrm{MoO}_{4}\right]^{2-}$ tetrahedra. Taking into account the effect of multi-molecular cluster structure, the corresponding multi-molecular cluster containing four structural units was also built and is exhibited in Figure 5b,c. The calculated Raman spectra of the cluster structure models by ab initio calculation are shown in Figure 4 after being corrected by a wavenumber scaling factor of 0.8555 and normalizing the intensity. Through comparative analysis, the calculated Raman frequencies and intensities are consistent with the data measured experimentally.

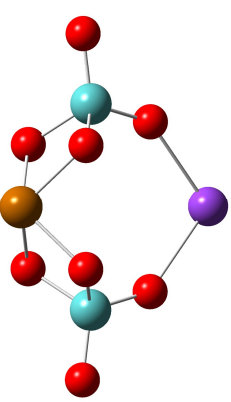

(a) $Q_{0}-C_{2 v}$

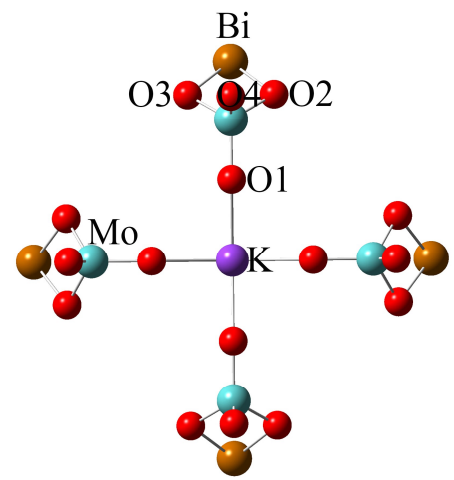

(b) $4 Q_{0}-D_{4 h}$

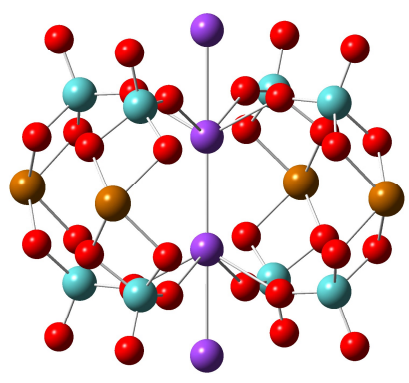

(c) $4 Q_{0}-D_{4 h}$

Figure 5. (a) The designed structural units and (b,c) the corresponding multi-molecular clusters structure for the ab initio calculation of molten Raman spectra of $\operatorname{KBi}\left(\mathrm{MoO}_{4}\right)_{2}$. Here, $(\mathbf{b}, \mathbf{c})$ represent the same cluster structure containing four molecules viewed from the in-plane and out-of-plane directions. The elements are labeled (Mo, light blue; $\mathrm{K}$, violet; $\mathrm{Bi}$, light brown; $\mathrm{O}$, red) in the diagram of $(\mathbf{b})$.

As can be seen from Figure 5, the structure models of anion motifs (a) represent a monomer $\left(Q_{0}\right)$ molecule of $\mathrm{KBi}\left(\mathrm{MoO}_{4}\right)_{2}$ with $C_{2 v}$ symmetry, and $(\mathrm{b}, \mathrm{c})$ represent the multi-molecular cluster structure with higher $D_{4 h}$ symmetry which consists of four monomers $\left(4 Q_{0}\right)$. In the anionic multi-molecular cluster structure, the environment of each $Q_{0}$ is equivalent. Figure 4 shows the calculated Raman spectra of a different number of model clusters of $\mathrm{KBi}\left(\mathrm{MoO}_{4}\right)_{2}$. The calculation result demonstrates that as the number of model clusters increases, the frequency of the characteristic peaks shifts toward a high wavenumber, which has been observed earlier caused by the multi-molecular cluster effect. Therefore, considering the environmental effects of cations, the more reliable multi-molecular cluster structure is closer to the real structure of the melt of $\mathrm{KBi}\left(\mathrm{MoO}_{4}\right)_{2}$. Through the combination of the experimental and calculation data, it is proved that the structure of the $\left[\mathrm{Bi}\left(\mathrm{MoO}_{4}\right)_{2}\right]^{-}$monomer with $\mathrm{Mo}^{6+}$ centers and $\mathrm{Bi}^{3+}$ sub-centers primarily presents in the melt of $\mathrm{KBi}\left(\mathrm{MoO}_{4}\right)_{2}$ molybdate and is distributed in a short-range ordered and long-range disordered state.

In Figure 4, the fitted Raman peak at $933 \mathrm{~cm}^{-1}$ originates from the symmetric stretching vibrations of non-bridging oxygens of $\mathrm{Mo}_{4} \mathrm{O}_{4}$. The peaks located at 898 and $842 \mathrm{~cm}^{-1}$ are attributed to the asymmetric stretching vibrations of non-bridging oxygens of $\mathrm{Mo}-\mathrm{O}_{1}$. The peak position at $761 \mathrm{~cm}^{-1}$ from calculation clearly shows the vibrations of the Bi-O bond with an oxygen coordination number of 4 . The wavenumber region of $450-770 \mathrm{~cm}^{-1}$ mainly involves the vibrations of $\mathrm{Bi}-\mathrm{O}$ in the structure. Table 3 lists the experimental 
and calculated wavenumbers of the major vibrational modes and their assignment in the melt of $\mathrm{KBi}\left(\mathrm{MoO}_{4}\right)_{2}$. For instance, the peak at $770 \mathrm{~cm}^{-1}$ was assigned to the symmetric scissor vibrations of $\mathrm{Bi}-\mathrm{O}_{2}$ and $\mathrm{Bi}_{-} \mathrm{O}_{3}$, whereas the asymmetric scissor vibrations of $\mathrm{Bi}-\mathrm{O}$ are around $720 \mathrm{~cm}^{-1}$. The peaks at about 394 and $327 \mathrm{~cm}^{-1}$ are caused by the asymmetric stretching and wagging vibrations of Mo-O in the clusters structure.

Table 3. The attribution of major vibrational modes in the melt of $\mathrm{KBi}\left(\mathrm{MoO}_{4}\right)_{2}$.

\begin{tabular}{|c|c|c|}
\hline \multicolumn{2}{|c|}{ Wavenumber/cm ${ }^{-1}$} & \multirow{2}{*}{ Type of Vibration } \\
\hline$v_{\text {exp. }}$ & $v_{\text {cal. }}$ & \\
\hline 933 & 924 & symmetric stretching vibrations of $\mathrm{Mo}^{-} \mathrm{O}_{4}$ \\
\hline 898 & 890 & \multirow{2}{*}{ asymmetric stretching vibrations of $\mathrm{Mo}-\mathrm{O}_{1}$} \\
\hline 842 & 842 & \\
\hline 770 & 761 & symmetric scissor vibrations of $\mathrm{Bi}-\mathrm{O}_{2}$ and $\mathrm{Bi}-\mathrm{O}_{3}$ \\
\hline 720 & 715 & asymmetric scissor vibrations of $\mathrm{Bi}-\mathrm{O}$ \\
\hline- & 595 & rocking vibrations of $\mathrm{Bi}-\mathrm{O}$ \\
\hline- & 466 & symmetric stretching vibrations of $\mathrm{Bi}-\mathrm{O}_{2}$ and $\mathrm{Bi}-\mathrm{O}_{3}$ \\
\hline 394 & 313 & \multirow{2}{*}{ asymmetric stretching and wagging vibrations of $\mathrm{Mo}-\mathrm{O}$} \\
\hline 327 & 267 & \\
\hline
\end{tabular}

\section{Conclusions}

In situ high-temperature Raman spectroscopy and quantum chemistry ab initio calculation were applied to investigate the structure present in the melt of $\mathrm{KBi}\left(\mathrm{MoO}_{4}\right)_{2}$ molybdates. The temperature-induced phase transition from monoclinic to the scheelite tetragonal structure was observed to occur at $833 \mathrm{~K}$ by temperature-dependent $\mathrm{XRD}$. The calculated results via the ab initio method are in good agreement with the experimental Raman data, demonstrating the reliability of the assignment of the observed Raman bands for the molten $\mathrm{KBi}\left(\mathrm{MoO}_{4}\right)_{2}$ at $1023 \mathrm{~K}$. The isolated structure of $\left[\mathrm{Bi}\left(\mathrm{MoO}_{4}\right)_{2}\right]^{-}$monomer anion, in which the oxygen coordination numbers of Mo and $\mathrm{Bi}$ atoms are both four and connected to each other by edge-sharing, is confirmed to exist primarily in the melt of $\mathrm{KBi}\left(\mathrm{MoO}_{4}\right)_{2}$. The study on the melt structure of $\mathrm{KBi}\left(\mathrm{MoO}_{4}\right)_{2}$ makes it possible to examine clusters structure composed of different complexes and $\mathrm{M}^{\mathrm{z}+}$ cations and opens up a new way for the exploration of the development of novel laser host materials.

Author Contributions: Conceptualization, M.W.; methodology and formal analysis, M.W., C.W., and J.Y.; software, M.W. and J.W.; data curation, M.W. and X.G.; writing - original draft preparation, M.W.; writing-review and editing, M.W., C.W., J.W., L.L., X.G., X.T., F.Z., and J.Y.; visualization, M.W., X.T., and F.Z.; supervision, J.Y. and L.L.; funding acquisition, M.W. and J.Y. All authors have read and agreed to the published version of the manuscript.

Funding: This research was funded by the National Natural Science Foundation of China (Grant No. 21773152) and Shanghai Committee of Science and Technology, China (Grant No. 12520709200). Wang thanks the China Postdoctoral Science Foundation (Grant No. 2019M661460) for support.

Conflicts of Interest: The authors declare no competing financial interest.

\section{References}

1. Hizhnyi, Y.; Nedilko, S.; Chornii, V.; Nikolaenko, T.; Zatovsky, I.; Terebilenko, K.; Boiko, R. Electronic structure and luminescence mechanisms in $\mathrm{M}^{\mathrm{I}} \mathrm{M}^{\mathrm{III}}\left(\mathrm{MoO}_{4}\right)_{2}$ molybdates. In Proceedings of the IEEE International Conference on Oxide Materials for Electronic Engineering (OMEE), Lviv, Ukraine, 3-7 September 2012; pp. 135-136. [CrossRef]

2. Yang, J.; Fu, P.; Lin, Z. Preparation of $\mathrm{KBi}\left(\mathrm{MoO}_{4}\right)_{2}$ nanocrystallite by solvothermal process and its gas-sensing properties. Mater. Res. Express 2018, 5, 065033. [CrossRef]

3. Vasylkiv, Y.; Kvasnyuk, O.; Shopa, Y.; Vlokh, R. Optical activity caused by torsion stresses: The case of NaBi $\left(\mathrm{MoO}_{4}\right)_{2}$ crystals. J. Opt. Soc. Am. A 2013, 30, 891-897. [CrossRef] [PubMed] 
4. Ryadun, A.A.; Nadolinny, V.A.; Tsydypova, B.N.; Pavlyuk, A.A. Electron paramagnetic resonance and photoluminescence of $\mathrm{NaBi}\left(\mathrm{MoO}_{4}\right)_{2}$ crystals doped with gadolinium ions. Phys. Solid State 2015, 57, 1188-1191. [CrossRef]

5. Adhikari, R.; Joshi, B.; Narro-García, R.; De la Rosa, E.; Lee, S.W. Microwave hydrothermal synthesis and infrared to visible upconversion luminescence of $\mathrm{Er}^{3+} / \mathrm{Yb}^{3+}$ co-doped bismuth molybdate nanopowder. J. Lumin. 2014, 145, 866-871. [CrossRef]

6. Mateos, X.; Solé, R.; Gavaldà, J.; Aguiló, M.; Massons, J.; Díaz, F. Crystal growth, optical and spectroscopic characterisation of monoclinic $\mathrm{KY}\left(\mathrm{WO}_{4}\right)_{2}$ co-doped with $\mathrm{Er}^{3+}$ and $\mathrm{Yb}^{3+}$. Opt. Mater. 2006, 28, $423-431$. [CrossRef]

7. Kasprowicz, D.; Drozdowski, M.; Majchrowski, A.; Michalski, E. Spectroscopic properties of $\left.\mathrm{KGd}_{(\mathrm{WO}}\right)_{2}$ : $(\mathrm{Er}, \mathrm{Yb})$ single crystals studied by Brillouin scattering method. Opt. Mater. 2007, 30, 152-154. [CrossRef]

8. Mateos, X.; Pujol, M.C.; Güell, F.; Solé, R.; Gavaldà, J.; Aguiló, M.; Díaz, F.; Massons, J. Sensitization of Er ${ }^{3+}$ emission at $1.5 \mu \mathrm{m}$ by $\mathrm{Yb}^{3+}$ in $\mathrm{KYb}\left(\mathrm{WO}_{4}\right)_{2}$ single crystals. Phys. Rev. B 2002, 66, 214104. [CrossRef]

9. Cheng, Z.X.; Zhang, S.J.; Song, F.; Guo, H.C.; Han, J.R.; Chen, H.C. Optical spectroscopy of Yb/Er codoped $\mathrm{NaY}\left(\mathrm{WO}_{4}\right)_{2}$ crystal. J. Phys. Chem. Solids 2002, 63, 2011-2017. [CrossRef]

10. Song, F.; Tan, H.; Shang, M.R.; Zhang, G.Y.; Cheng, Z.X.; Chen, H.C. Spectra characteristics of $\operatorname{Er}^{3+}$ doped $^{2}$ $\mathrm{NaY}\left(\mathrm{WO}_{4}\right)_{2}$ crystal. Acta Phys. Sin. 2002, 51, 2375-2379.

11. Huang, J.H.; Gong, X.H.; Chen, Y.J.; Lin, Y.F.; Liao, J.S.; Chen, X.Y.; Luo, Z.D.; Huang, Y.D. Polarized spectral properties of $\mathrm{Er}^{3+}$ ions in $\mathrm{NaGd}\left(\mathrm{WO}_{4}\right)_{2}$ crystal. Appl. Phys. B 2007, 89, 73-80. [CrossRef]

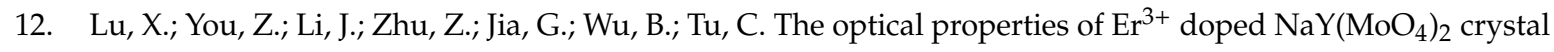
for laser applications around $1.5 \mu \mathrm{m}$. J. Alloys Compd. 2006, 426, 352-356. [CrossRef]

13. Kuz'micheva, G.M.; Lis, D.A.; Subbotin, K.A.; Rybakov, V.B.; Zharikov, E.V. Growth and structural X-ray investigations of scheelite-like single crystals Er, Ce:NaLa( $\left(\mathrm{MoO}_{4}\right)_{2}$ and $\mathrm{Yb}: \mathrm{NaGd}\left(\mathrm{WO}_{4}\right)_{2}$. J. Cryst. Growth 2005, 275, e1835-e1842. [CrossRef]

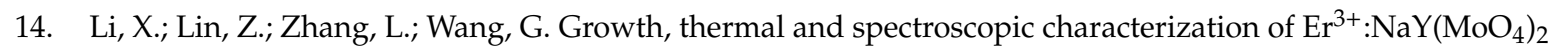
crystal. J. Cryst. Growth 2006, 293, 157-161. [CrossRef]

15. Li, X.; Lin, Z.; Zhang, L.; Wang, G. Growth, thermal and spectral properties of $\mathrm{Nd}^{3+}$-doped $\left.\mathrm{NaGd}_{(\mathrm{MoO}}\right)_{2}$ crystal. J. Cryst. Growth 2006, 290, 670-673. [CrossRef]

16. Sardar, D.K.; Russell, C.C., III; Yow, R.M.; Gruber, J.B.; Zandi, B.; Kokanyan, E.P. Spectroscopic analysis of the $\mathrm{Er}^{3+}\left(4 f^{11}\right)$ absorption intensities in $\mathrm{NaBi}\left(\mathrm{WO}_{4}\right)_{2}$. J. Appl. Phys. 2004, 95, 1180-1184. [CrossRef]

17. Rico, M.; Méndez-Blas, A.; Volkov, V.; Monge, M.Á.; Cascales, C.; Zaldo, C.; Kling, A.; Fernández-Díaz, M.T. Polarization and local disorder effects on the properties of $\mathrm{Er}^{3+}$-doped $\mathrm{XBi}\left(\mathrm{YO}_{4}\right)_{2}, \mathrm{X}=\mathrm{Li}$ or $\mathrm{Na}$ and $\mathrm{Y}=\mathrm{W}$ or Mo, crystalline tunable laser hosts. J. Opt. Soc. Am. B 2006, 23, 2066-2078. [CrossRef]

18. Isupov, V.A. Binary molybdates and tungstates of monoand trivalent elements as possible ferroelastics and ferroelectrics. Ferroelectrics 2005, 321, 63-90. [CrossRef]

19. Wang, M.; You, J.; Sobol, A.A.; Lu, L.; Wang, J.; Xie, Y. In-situ studies of structure transformation and Al coordination of $\mathrm{KAl}\left(\mathrm{MoO}_{4}\right)_{2}$ during heating by high temperature Raman and ${ }^{27} \mathrm{Al} \mathrm{NMR}$ spectroscopies. Materials 2017, 10, 310. [CrossRef]

20. Li, K.; Deun, R.V. Low-temperature solid-state synthesis and upconversion luminescence properties in $(\mathrm{Na} / \mathrm{Li}) \mathrm{Bi}\left(\mathrm{MoO}_{4}\right)_{2}: \mathrm{Yb}^{3+}, \mathrm{Er}^{3+}$ and color tuning in $(\mathrm{Na} / \mathrm{Li}) \mathrm{Bi}\left(\mathrm{MoO}_{4}\right)_{2}: \mathrm{Yb}^{3+}{ }_{,} \mathrm{Ho}^{3+}, \mathrm{Ce}^{3+}$ phosphors. Inorg. Chem. 2019, 58, 6821-6831. [CrossRef]

21. Amarasinghe, D.K.; Perera, S.S.; Rabuffetti, F.A. Rotational disorder in scheelite-type $\mathrm{NaRE}\left(\mathrm{MO}_{4}\right)_{2}$ (RE = Rare-Earth, Y; M = Mo, W). Cryst. Growth Des. 2020, 20, 3442-3448. [CrossRef]

22. Atuchin, V.V.; Aleksandrovsky, A.S.; Bazarov, B.G.; Bazarova, J.G.; Chimitova, O.D.; Denisenko, Y.G.; Gavrilova, T.A.; Krylov, A.S.; Maximovskiy, E.A.; Molokeev, M.S.; et al. Exploration of structural, vibrational and spectroscopic properties of self-activated orthorhombic double molybdate $\mathrm{RbEu}\left(\mathrm{MoO}_{4}\right)_{2}$ with isolated $\mathrm{MoO}_{4}$ units. J. Alloys Compd. 2019, 785, 692-697. [CrossRef]

23. Dudnikova, V.B.; Zharikov, E.V.; Eremin, N.N. Local structure of molybdates solid solutions containing europium by results of atomistic simulation. Mater. Today Commun. 2020, 23, 101180. [CrossRef]

24. Voda, M.; Balda, R.; Sáez de Ocáriz, I.; Lacha, L.M.; Illarramendi, M.A.; Fernández, J. Spectroscopic properties of rare earths in $\mathrm{K}_{5} \mathrm{Bi}_{1-\mathrm{x}}(\mathrm{RE})_{\mathrm{x}}\left(\mathrm{MoO}_{4}\right)_{4}$ crystals. J. Alloys Compd. 1998, 275-277, 214-218. [CrossRef]

25. Huang, X.; Wang, G. Growth and optical characteristics of $\mathrm{Er}^{3+}: \mathrm{LiLa}\left(\mathrm{MoO}_{4}\right)_{2}$ crystal. J. Alloys Compd. 2009, 475, 693-697. [CrossRef] 
26. Yan, B.; $\mathrm{Wu}$, J.H. $\mathrm{NaY}\left(\mathrm{MoO}_{4}\right)_{2}: \mathrm{Eu}^{3+}$ and $\mathrm{NaY}_{0.9} \mathrm{Bi}_{0.1}\left(\mathrm{MoO}_{4}\right)_{2}: \mathrm{Eu}^{3+}$ submicrometer phosphors: Hydrothermal synthesis assisted by room temperature-solid state reaction. microstructure and photoluminescence. Mater. Chem. Phys. 2009, 116, 67-71. [CrossRef]

27. Zhou, D.; Pang, L.X.; Guo, J.; Wang, H.; Yao, X.; Randall, C. Phase evolution, phase transition, Raman spectra, infrared spectra, and microwave dielectric properties of low temperature firing $\left(\mathrm{K}_{0.5 \mathrm{x}} \mathrm{Bi}_{1-0.5 \mathrm{x}}\right)\left(\mathrm{Mox}_{\mathrm{x}} \mathrm{V}_{1-\mathrm{x}}\right) \mathrm{O}_{4}$ ceramics with scheelite related structure. Inorg. Chem. 2011, 50, 12733-12738. [CrossRef]

28. Hanuza, J.; Maczka, M.; van der Maas, J.H. Vibrational characteristics of the single-bridge MoOMo and double-bridge $\mathrm{MoO}_{2} \mathrm{Mo}$ intermolecular interactions-polarized infrared and Raman spectra of monoclinic $\mathrm{KBi}\left(\mathrm{MoO}_{4}\right)_{2}$ single crystal. Vib. Spectrosc. 1995, 8, 417-423. [CrossRef]

29. Klevtsov, P.V.; Klevtsova, R.F. Polymorphism of the double molybdates and tungstates of mono-and trivalent metals with the composition $\mathrm{M}^{+} \mathrm{R}^{3+}\left(\mathrm{EO}_{4}\right)_{2}$. J. Struct. Chem. 1977, 18, 339-355. [CrossRef]

30. You, J.L.; Jiang, G.C.; Hou, H.Y.; Chen, H.; Wu, Y.Q.; Xu, K.D. Quantum chemistry study on superstructure and Raman spectra of binary sodium silicates. J. Raman Spectrosc. 2005, 36, 237-249. [CrossRef]

31. Labet, V.; Colomban, P. Vibrational properties of silicates: A cluster model able to reproduce the effect of "SiO 4 " polymerization on Raman intensities. J. Non Cryst. Solids 2013, 370, 10-17. [CrossRef]

32. Hay, P.J.; Wadt, W.R. Ab initio effective core potentials for molecular calculations. Potentials for the transition metal atoms Sc to Hg. J. Chem. Phys. 1985, 82, 270-283. [CrossRef]

33. Lee, T.J.; Jayatilaka, D. An open-shell restricted Hartree-Fock perturbation theory based on symmetric spin orbitals. Chem. Phys. Lett. 1993, 201, 1-10. [CrossRef]

34. Hamann, D.R.; Schlüter, M.; Chiang, C. Norm-conserving pseudopotentials. Phys. Rev. Lett. 1979, 43, 1494. [CrossRef]

35. Kisel, N.G.; Mokhosoev, M.V. Potassium and bismuth double molybdates. Ukr. Khim. Zh. 1972, 38, 743-745.

36. Klevtsov, P.V.; Vinokurov, V.A.; Klevtsova, R.F. Double molybdates and tungstates of alkali metals with bismuth, $\mathrm{M}^{+} \mathrm{Bi}\left(\mathrm{TO}_{4}\right)_{2}$. Kristallografiya 1973, 18, 1192-1197.

37. Klevtsov, P.V.; Vinokurov, V.A. Phase transformation in $\mathrm{KBi}\left(\mathrm{MoO}_{4}\right)_{2}$ crystals. Kristallografiya 1974, $19,763-767$.

38. Voronko, Y.K.; Sobol, A.A.; Shukshin, V.E. Raman scattering study of molten alkali-metal molybdates and tungstates rich in basic oxides. Inorg. Mater. 2014, 50, 844-849. [CrossRef]

39. Wang, M.; You, J.; Sobol, A.A.; Wang, J.; Wu, J.; Lv, X. Temperature-dependent Raman spectroscopic studies of microstructure present in dipotassium molybdate crystals and their melts. J. Raman Spectrosc. 2016, 47, 1259-1265. [CrossRef]

40. Wang, M.; Simon, P.; Lu, L.; Sobol, A.A.; Wang, J.; Wan, S.; You, J. Quantitative studies on the structure of molten binary potassium molybdates by in situ Raman spectroscopy and quantum chemistry ab initio calculations. Anal. Chem. 2018, 90, 9085-9092. [CrossRef]

Publisher's Note: MDPI stays neutral with regard to jurisdictional claims in published maps and institutional affiliations.

(C) 2020 by the authors. Licensee MDPI, Basel, Switzerland. This article is an open access article distributed under the terms and conditions of the Creative Commons Attribution (CC BY) license (http://creativecommons.org/licenses/by/4.0/). 